\title{
The age-composition of field populations and the survival rates in Culex tritaeniorhynchus Giles
}

\author{
Kazuo BuÉ:* and Sumiyo Iто* \\ Laboratory of Medical Zoology, Osaka Prefectural Institute \\ of Public Health, Higashinari-ku, Osaka, Osaka 537, Japan
}

(Received: July 24, 1981)

\begin{abstract}
The age-composition of natural populations of Culex tritaeniorhynchus was investigated in a rural district of Osaka Prefecture during the period from 1968 to 1973, and it was found that the seasonal fluctuations in the age-composition of $C x$. tritaeniorhynchus populations were well correlated to the variation of mosquito abundance. The average parous rate of the populations was slightly higher in August (18.1\%) than in July $(15.4 \%)$. The daily survival rate of the female mosquitoes were thus estimated as 0.525 in July and as 0.555 in August, respectively. There was little difference in the daily survival rates among different years.
\end{abstract}

\section{INTRODUCTION}

The information on the age-composition of mosquito populations in the field is important to understand the spread of Japanese encephalitis virus (JEV) by mosquitoes.

It was shown by Hayashi and Kurihara (1965) that the physiological age of female Culex tritaeniorhynchus could be estimated by the determination of the count of follicular dilatations. So far, some few reports on the age-composition of natural populations of $C x$. tritaeniorhynchus have been published ( $\mathrm{Ha}$ rada et al., 1967; Sasa et al., 1968; Buéi et al., 1968; Yajima et al., 1971). Moreover, Davidson (1955) reported that the survival rate could be calculated from the square root of the proportion parous if the gonotrophic cycle occupied 2 days.

Recently, we studied the gonotrophic cycle of the Cx. tritaeniorhynchus mosquitoes inhabited in the field, and found that the time period of blood meal interval was 2.9 days in

* 武衛和雄, 伊藤寿美代：大阪府立公衆衛生研究所 (于537 大阪市東成区中道 1 丁目 3-69) the midst of summer season (Buéi et al., 1980).

Based on the findings above, we investigated the seasonal age-composition of $C x$. tritaeniorhynchus for 6 years from 1968 to 1973, and made an attempt to estimate the survival rate of $C x$. tritaeniorhynchus populations in nature. The data obtained are presented in this paper.

\section{Materials And Methods}

\section{The study site}

The investigation was carried out from June 1968 to September 1973 at Kurotori Village of Izumi City. The village is located within a distance of $30 \mathrm{~km}$ from Osaka City. The climate in summer was hot, the average temperature in August was $28^{\circ} \mathrm{C}$, but in winter, it is relatively mild, the average temperature of $4^{\circ} \mathrm{C}$ in January. The average annual rainfall is around $1,300 \mathrm{~mm}$.

\section{Mosquito sampling}

$C x$. tritaeniorhynchus were collected at a cowshed. For determination of physiological age, the mosquitoes were caught by waving a 
hand-hold net for $1 \mathrm{hr}$ period just after sunset, 1 or 2 nights per week. For estimation of population densities, the mosquitoes were caught by a light trap, which was operated inside cowshed from dusk to dawn. The collections were made consecutively every night during 4 months.

\section{Age-grading methods}

Unengorged females of Cx. tritaeniorhynchus were dissected in physiological saline. Either piece of the ovaries of individual mosquito was dried and examined for the absense of tracheolar coiling, by which the parous mosquitoes were selected (Detinova, 1962). In the mosquito which was found to be parous or doubtful, the remaining piece of the ovaries was kept in saline and further dissected with a sharpen wire needle for examination of the ovariolar dilatations.

\section{Results}

Age-composition of natural populations of Cx. tritaeniorhynchus

The age-composition of the populations in each month of the summer season is given in Table 1. About $82 \%$ of the total catch of Cx. tritaeniorhynchus were nulliparous females, about $18 \%$ 1-parous females, and a few 2-parous females. Three-parous or older females were not obtained.

The parous rates of mosquito populations varied from 18 to $42 \%$ in June, from 8 to $21 \%$ in July, and from 12 to $24 \%$ in August varied from 18 to $42 \%$ in June, from 8 to 1973. The average parous rate of the population in August retained 18.1\%, being slightly higher than that in July $(15.4 \%)$.

\section{Seasonal change of age-composition}

The seasonal change of the nulliparous rates of $C x$. tritaeniorhynchus populations is shown as the weekly mean values in Fig. 1. The percentage of nulliparous females increased from July to the first week of September, and thereafter, it decreased markedly.

The seasonal abundance of $C x$. tritaeniorhynchus is shown in Fig. 2. The size of the mosquito population was expressed by the modified geometric mean known as the Williams' mean. A main peak of abundance of Cx. tritaeniorhynchus was seen between the late July and early August when the percentages of nulliparous females were very high. This indicated that a large number of

Table 1 Percentage of age-composition and daily survival rates of Culex tritaeniorhynchus at Kurotori, Izumi City, Osaka Prefecture

\begin{tabular}{|c|c|c|c|c|c|c|}
\hline \multirow{2}{*}{ Year } & \multirow{2}{*}{ Month } & \multirow{2}{*}{$\begin{array}{l}\text { No. of } \\
\text { dissected }\end{array}$} & \multicolumn{3}{|c|}{$\begin{array}{l}\text { Physiological } \\
\text { age-group* }\end{array}$} & \multirow{2}{*}{$\begin{array}{l}\text { Daily } \\
\text { survival } \\
\text { rate }\end{array}$} \\
\hline & & & $\mathrm{N}$ & $1-P$ & $2-\mathrm{P}$ & \\
\hline \multirow{3}{*}{1968} & June & 70 & 61.4 & 37.1 & 1.4 & 0.720 \\
\hline & July & 140 & 86.4 & 13.6 & 0 & 0.503 \\
\hline & August & 203 & 86.2 & 13.3 & 0.5 & 0.505 \\
\hline \multirow{3}{*}{1969} & June & 88 & 67.0 & 33.0 & 0 & 0.682 \\
\hline & July & 285 & 91.9 & 8.1 & 0 & 0.420 \\
\hline & August & 427 & 87.6 & 12.4 & 0 & 0.487 \\
\hline \multirow{3}{*}{1970} & June & 84 & 82.1 & 17.9 & 0 & 0.553 \\
\hline & July & 553 & 84.6 & 15.2 & 0.2 & 0.525 \\
\hline & August & 697 & 83.4 & 16.2 & 0.4 & 0.538 \\
\hline \multirow{3}{*}{1971} & June & 185 & 69.2 & 29.2 & 1.6 & 0.666 \\
\hline & July & 551 & 83.3 & 16.5 & 0.2 & 0.540 \\
\hline & August & 480 & 18.7 & 18.1 & 0.2 & 0.557 \\
\hline \multirow{3}{*}{1972} & June & 119 & 58.0 & 42.0 & 0 & 0.741 \\
\hline & July & 423 & 82.5 & 17.0 & 0.5 & 0.548 \\
\hline & August & 400 & 75.8 & 23.0 & 1.3 & 0.613 \\
\hline \multirow{2}{*}{1973} & July & 278 & 79.1 & 20.5 & 0.4 & 0.583 \\
\hline & August & 237 & 76.4 & 22.8 & 0.8 & 0.608 \\
\hline \multicolumn{2}{|c|}{ Total } & 5,220 & 81.5 & 18.1 & 0.4 & \\
\hline \multirow{3}{*}{ Mean } & June & 546 & 67.5 & 31.8 & 0.6 & 0.679 \\
\hline & July & 2,230 & 84.6 & 15.2 & 0.2 & 0.525 \\
\hline & August & 2,444 & 81.9 & 17.6 & 0.5 & 0.555 \\
\hline
\end{tabular}

* $\mathrm{N}$ : Nulliparous, 1-P: 1-parous, 2-P: 2-parous.

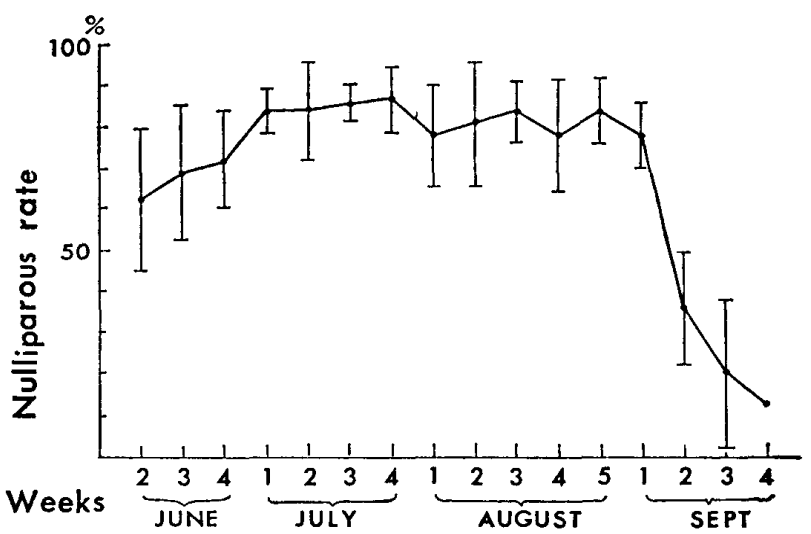

Fig. 1 Weekly mean values of nulliparous rates of populations of Cx. tritaeniorhynchus from 1968 to 1973 

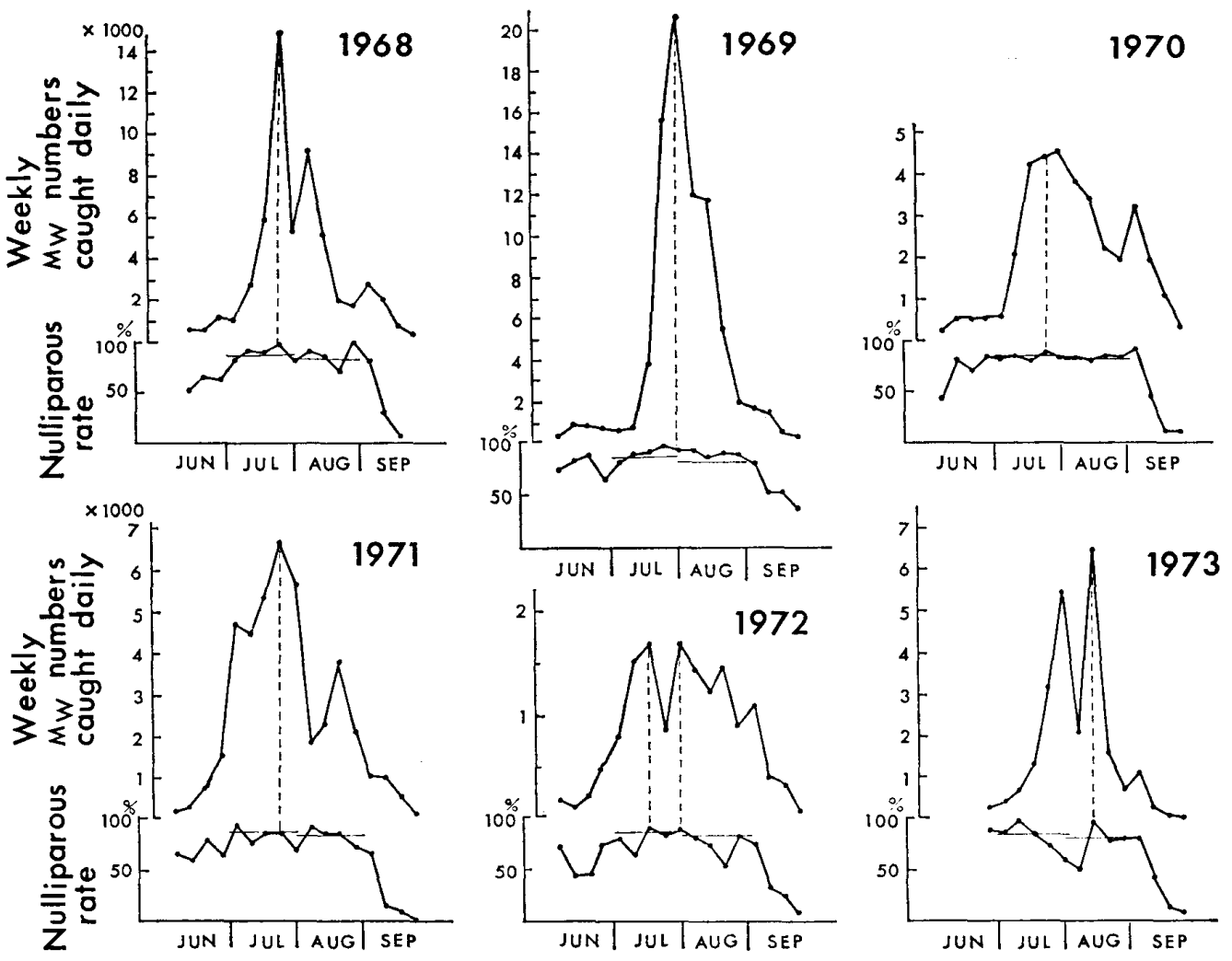

Fig. 2 Seasonal changes of the weekly mean numbers of females and the nulliparous rates in Culex tritaeniorhynchus populations at the Kurotori area, Izumi City, Osaka Prefecture, 1968-1973

Table 2 The expectation of transmissive life of Culex tritaeniorhynchus at a rural district in Osaka

\begin{tabular}{lll} 
& July & August \\
\hline Parous rate & 0.154 & 0.181 \\
Gonotrophic cycle (days) & 2.9 & 2.9 \\
Daily survival rate, $p$ & 0.525 & 0.555 \\
$\begin{array}{l}\left.\text { Life expectancy, 1/(- } \log _{e} p\right) \\
\quad 1.55\end{array}$ & 1.70 \\
$\begin{array}{l}\text { Extrinsic incubation period } \\
\text { in days, } n\end{array}$ & 10 & 10 \\
$\begin{array}{l}\text { Rate of survival till being } \\
\text { transmissive, } p^{n}\end{array}$ & 0.00159 & 0.00277 \\
$\begin{array}{l}\text { Expectancy of transmissive } \\
\quad \text { life, } p /\left(-\log _{e} p\right)\end{array}$ & 0.00247 & 0.00470 \\
\hline
\end{tabular}

young mosquitoes were emerging during that period. Therefore, it seems to be reasonable to conclude that the fluctuations in the nulliparous rate were correlated to the changes in mosquito abundance.

\section{Daily survival rate}

The estimated daily survival rates in $C x$. tritaeniorhynchus populations are shown in
Table 1. The average daily survival rates of the mosquitoes in July and August were calculated as 0.525 and 0.555 , respectively.

With regard to the JEV infection of $C x$. tritaeniorhynchus, the life expectancy of infective mosquitoes could be calculated using the McDonald's formula (McDonald, 1973). In Table 2, are shown the calculated values of infective life expectancy of $C x$. tritaeniorhynchus in July and August. The life expectancy of mosquitoes, $-1 / \log _{e} p$, was estimated as 1.55 day in July and as 1.70 day in August. The former was slightly shorter than the latter.

Takahashi (1976) made the close experiments on the JEV secretion of Cx. tritaeniorhynchus, and clarified that the majority of infected mosquitoes emerged in mid-summer will become virus-transmissive on day 10 after the infection. The rate of the infected mosquitoes surviving until being transmissive is then given by $p^{n}$, where $n$ represents the period in days required to render $C x$. tritaeniorhynchus transmissible. The surviving rate calculated was 0.00159 in July and 
0.00277 in August. Using these values, the expectancy of transmissive life of the mosquito was calculated by $-p^{n} / \log _{e} p$ as 0.00247 in July and 0.00470 in August.

\section{Discussion}

Detinova (1962) studied the age-composition of populations of Anopheles maculipennis in Moscow and reported that very old females, in their tenth to twelfth gonotrophic cycle, were found almost daily in July, and that the nulliparous rate of females during the whole season was smaller than the uniparous rate of females. She concluded that the deficit of nulliparous females in nature was caused by the greater proportion of the physiologically young females remained in nature.

Gillies and Wilkes (1965) studied the agecomposition of populations of Anopheles gambiae and An. funestus in Tanzania, in which the oldest mosquitoes that he found were one 12-parous female of gambiae, and two females of funestus those had at least 13 and 14 dilatations, respectively. Samarawickrema (1968) also found 5-parous females of Mansonia uniformis as the oldest mosquitoes in Ceylon (Sri Lanka).

Corbet (1963) showed that the parous rate of mosquito populations differed markedly among species. It is generally shown that the parous rates of mosquitoes are high in the tropics probably owing to their longer survival (Laurence, 1963; de Meillon et al., 1967; Samarawickrema, 1967, 1968; Kay, 1979).

In Japan, the parous females of field populations of Cx. tritaeniorhynchus were found to be 1 - to 3-parous, and the most of them were 1-parous (Harada et al., 1967; Yajima et al., 1971). The parous mosquitoes of $C x$. tritaeniorhynchus, as far as we examined, consisted mostly of the 1-parous females as shown in Table 1, which suggests their shorter survival in nature. The same trend was also demonstrated in the mosquito survey in Okayama Prefecture (Sasa et al., 1968).

It was reported that there was little monthly fluctuation in the natural mortality of $C x$. fatigans in Burma (de Meillon et al., 1967) and also in that of $C x$. fatigans and $M$. uni- formis in Ceylon (Sri Lanka) (Samarawickrema, 1967, 1968). On the other hand, Reuben (1963) found the seasonal fluctuation of the natural mortality of Culex vishnui in South India. He reported that the estimated mortality of $C x$. vishnui was low during the period from August to January, ranging from 6 to $14 \%$, whereas it was higher namely in the period from February to July. He also pointed out that the season of JEV transmission in this area corresponded to the season when the mosquito mortality was low.

In Osaka Prefecture, the recent greatest outbreak of human JE (346 patients) occurred in 1966. We reported in the previous paper that the parous rate of the population of Cx. tritaeniorhynchus in that year was $20.8 \%$ in July and $27.4 \%$ in August (Buéi et al., 1968). The estimated probability of mosquito survival through 1 day was 0.582 in July and 0.640 in August. These values were not so much different from the survival rates of mosquitoes which were obtained in the period from 1968 to 1973 .

As seen in Table 2, the proportion of infected $C x$. tritaeniorhynchus which would survive for 10 days was extremely small. The actual threshold density was calculated as $1 / 0.00159=629$ in July, and $1 / 0.00227=361$ in August. Based on these findings, it would be supposed that only 1 mosquito might survive long enough to transmit JEV to a host out of 629 or 361 mosquitoes infected originally.

From such a view point, it may be concluded that the abundance of $C x$. tritaeniorhynchus must be an important factor enlarging JE epidemics.

\section{AGknowledgements}

We wish to thank Mrs. and Mr. Yamaguchi for their help in the collection of mosquitoes. We are grateful to Dr. Nobuko Ikegami of Osaka Prefectural Institute of Public Health for her critical reading of this manuscript.

\section{REFERENGES}

Buéi, K., H. Arai, N. Ueba, S. Nakajima and A. Maeda (1968): Ecological studies on Culex tritaeniorhynchus and their natural infection with Japanese encephalitis virus in Osaka Prefecture. Jap. J. Sanit. Zool., 19: 237-248. 
Buéi, K., S. Ito, H. Nakamura and M. Yoshida (1980): Field studies on the gonotrophic cycle of Culex tritaeniorhynchus. Jap. J. Sanit. Zool., 31: $57-62$.

Corbet, P. S. (1963): Seasonal patterns of agecomposition of sylvan mosquito populations in Uganda. Bull. Entomol. Res., 54: 213-227.

Davidson, G. (1955): Measurement of the ampulla of the oviduct as a means of determining the natural daily mortality of Anopheles gambiae. Ann. Trop. Med. Parasitol., 49: 24-36.

De Meillon, B., B. Grab and A. Sebastian (1967): Evaluation of Wuchereria bancrofti infection in Culex pipiens fatigans in Rangoon, Burma. Bull. Wld Hlth Org., 36: 91-100.

Detinova, T. S. (1962): Age-grouping Methods in Diptera of Medical Importance, 216 pp., W.H.O., Geneva.

Gillies, M. T. and T. J. Wilkes (1965): A study of the age-composition of populatoins of Anopheles gambiae Giles and Anopheles funestus Giles in northeastern Tanzania. Bull. Entomol. Res., 56: 237-262.

Harada, F., K. Moriya and T. Yabe (1967): Observations on the habits of feeding and oviposition of Culex tritaeniorhynchus Giles. Jap. J. Appl. Entomol. Zool., 11: 83-89.

Hayashi, S. and T. Kurihara (1965): Studies on the age of mosquitoes. I. The determination of physiological age of Culex pipiens pallens by the relics formed at ovarioles after the oviposition. Jap. J. Sanit. Zool., 16: 29-33.

Kay, B. H. (1979): Age structure of populations of Culex annulirostris at Kowanyama and Charleville, Queensland. J. Med. Entomol., 16: 309-316.

Laurence, B. R. (1963): Natural mortality in two filarial vectors. Bull. Wld Hlth Org., 28: 229-234.

McDonald, G. (1973): Dynamics of Tropical Disease, pp. 115-130, Oxford Univ. Press, London.

Reuben, R. (1963) : Natural mortality in mosquitoes of the Culex vishnui group in South India. Indian J. Malariol, 17: 223-231.

Samarawickrema, W. A. (1967): A study of the age-composition of natural populations of Culex pipiens fatigans Wiedemann in relation to the transmission of filariasis due to Wuchereria bancrofti (Cobbold) in Ceylon. Bull. Wld Hlth Org., 37: 117-137.

Samarawickrema, W. A. (1968): Biting cycles and parity of the mosquito Mansonia uniformis in Ceylon. Bull. Entomol. Res., 58: 299-314.

Sasa, M., Y. Wada, M. Watanabe, M. Yasuno, S. Hirakoso, A. Shirasaka, T. Umino, K. Kamimura, A. Ishii, I. Kitago, S. Inatomi, K. Itano and S. Suguri (1968): Some observations on the behavior of Culex tritaeniorhynchus summorosus, the principal vector of Japanese encephalitis in Japan. Jap. J. Exp. Med., 38: 289-325.

Takahashi, M. (1976): The effects of environmental and physiological conditions of Culex tritaeniorhynchus on the pattern of transmission of Japanese encephalitis virus. J. Med. Entomol., 13: 275-284.

Yajima, T., S. Yoshida and T. Watanabe (1971): Ecological studies on the population of adult mosquito, Culex tritaeniorhynchus summorosus Dyar: The diurnal activity in relation to the physiological age. Jap. J. Ecol., 21 : 204-214.

$$
\begin{gathered}
\text { 摘 要 } \\
\text { コガタアカイエカの年令構成と生存率 }
\end{gathered}
$$

日本脳㷋ウイルスをとりこんだコガタアカイエカが 伝播可能上なるまで，どのくらいの割合で生存してい るかを推定することは，その地域での伝播の度合を知 るうえに必要なことである。

大阪府下のある地域で採集したコガタアカイエカ個 体群について，1968～1973年の 6 年間, 年令構成の季 節的, 年次的に变動する様相を観察した. その結果, 末 経産蚊率の変動は蚊の発生数の変化によって生ずるこ 上，8月の平均経座率 (18.1\%) は7月のそれ (15.4\%o ) に比ベてわずかに高いことを示した。

ききに報告したごとく, 本蚊の野外における gonotrophic cycle は2.9日であったので，これらから日あ たりの生存率が推定された。すなわち，7月は 0.525 , 8 月は 0.555 であった。これらの值の年による変動は さほ上゙大きくはないように思われる。 